\title{
The role of asymmetry in the interplay between internal and external factors: Empirical evidence from the US, Brazil, Canada and Mexico*
}

\author{
Kaya Tokmakcioglu ${ }^{1}$, Oguzhan Ozcelebi ${ }^{2}$, Ali Sezin Ozdemir ${ }^{3}$
}

\begin{abstract}
In this study, the real economic activity and monetary policy in the US are examined in comparison with the foreign trade balance and exchange rates, using Qual VAR and nonlinear VAR models. We found that the foreign trade with Brazil, Canada and Mexico do not lead to a possible recession in the US. The value of the domestic currency of Brazil, Canada and Mexico against the US dollar does not contribute to a possible recession over the foreign exchange market. We also show that a contraction in the US economy and contractionary monetary policy will lead to the appreciation of the US dollar by leading to capital inflows. Although the shadow interest rate may have asymmetric effects on the foreign trade balance with Canada and USD/CAD, we find that the foreign trade balance with Mexico and USD/MXN will be affected positively/negatively by an increase/decrease in the shadow interest rate.
\end{abstract}

Key words: shadow interest rate, exchange rate, foreign trade balance, Qual VAR, non-linear VAR

JEL classification: E44, F31, F41

\footnotetext{
* Received: 17-02-2019; accepted: 13-06-2019

1 Associate Professor, Faculty of Management Engineering, Department of Management Engineering, Istanbul Technical University. Macka Campus, 34343 Besiktas, Istanbul, Turkey. Scientific affiliation: monetary economics, international economics, finance. Phone: +90 212 2931300 (205-113).E-mail: tokmakcioglu@itu.edu.tr.

2 Associate Professor, Faculty of Economics, Department of Economics, Istanbul University. Beyazit Campus, 34542 Beyazit, Istanbul, Turkey. Scientific affiliation: monetary economics, international economics, macroeconomics, applied economics, DSGE modeling. Phone: +90 2124400000 (11789).Fax: +90 $2125208682 . E$-mail: ogozc@istanbul.edu.tr.

3 PhD Candidate, Faculty of Management Engineering, Department of Management Engineering, Istanbul Technical University. Macka Campus, 34343 Besiktas, Istanbul, Turkey. Scientific affiliation: monetary economics, international economics, finance. Phone: +90 2122931300 (205-113).E-mail: ozdemiralisezin@gmail.com.
} 


\section{Introduction}

After the global financial crisis (GFC) of 2008-2009, global liquidity conditions significantly deteriorated, and the international trade volume was negatively affected. In order to overcome this crisis, the central banks of developed countries, and in particular the Fed, have implemented quantitative easing (QE) policies that have international effects. In this context, monetary policy can be classified as conventional or unconventional, and the impact of the international spillover effects of monetary policy has been the subject of many studies (Chen et al., 2016; Potjagailo, 2017; Hajek and Horvath, 2018; Rohit and Dash, 2018). Additionally, the identification of the transmission mechanism of monetary policy with indicators reflecting unconventional monetary policy has gained importance in terms of raising its effectiveness. The shadow interest rate developed by Krippner (2014) has been widely used, and the international spillover effects of a particular monetary policy have frequently been examined based on the financial sector (Barbosa et al., 2018; Gajewski et al., 2019).

The international spillover effects of the shadow interest rate cannot be measured solely through financial variables, and may even influence international trade flows and cause current account imbalances. Since changes in the current account balance determine external financing needs, this may increase the pressure on the currency market and lead to financial crises. In view of this, the number of studies examining the relationship between monetary policy and foreign trade increased following the GFC (Barakchian, 2015; Aizenman et al., 2016; Apostolou and Beirne, 2018). There are also studies in the literature that are based on the assumption that a current account imbalance can trigger a financial crisis (Unger, 2017; Hjortsoe et al., 2018). Most recently, Hjortsoe et al. (2018) explored the possible impacts of expansionary monetary policy on the current account balance by building a DSGE model and estimating a Bayesian panel VAR model. In this framework, they used a varying coefficient in the Bayesian panel VAR model to represent the degree of financial, product and labor market regulation in 19 OECD countries. In this way, they verified the impact of a low interest rate policy on the current account deficit before the GFC. Because the formulation of monetary policy has changed since the GFC, it has become crucial to incorporate the possible role of the shadow interest rate into an analysis of the current account balance.

In this paper, we employ a Qualitative VAR (Qual VAR) approach, as proposed by Dueker (2005), to examine the interplay between real economic activity, the shadow interest rate, the exchange rate and the foreign trade balance in the US, Brazil, Canada and Mexico. Since the impacts of changes in interest rates on macroeconomic and financial variables may have different magnitudes and contrary effects, the nonlinear relationships among the variables are evaluated here in terms of the asymmetric effects rather than by estimating the time-varying coefficients, as 
in Hjortsoe et al. (2018). A nonlinear VAR model based on Kilian and Vigfusson (2011) is also estimated using monthly data from 2010:01 to 2018:02, since real economic activity is at the heart of both models. More specifically, the Qual VAR employs an OECD-based recession indicator of the US as the latent variable of the model, which takes values of one (peak) and zero (trough) values. We also investigate the role of the asymmetry in the relationship between model variables using the censored variable approach of Kilian and Vigfusson (2011). In this way, real economic activity is represented by the growth of industrial production in the nonlinear VAR model.

The aim of our study is twofold: (i) to detect the responsiveness of the dependent variables, both in the Qual VARs and the nonlinear VARs, to shocks in the real economic activity and the shadow interest rate with impulse response functions (IRFs); and (ii) to identify the existence of asymmetry in the relationship between the model variables, using IRFs and slope-based tests. Hence, we investigate whether changes in the real economic activity and the shadow interest rate have significant effects on the exchange rate and the foreign trade balance between the US, Brazil, Canada and Mexico. We contribute to the existing literature by addressing the issue of whether the macroeconomic conjuncture and the monetary policy stance may be the major sources of the movements in the exchange rates and thus the foreign trade flows between these countries. Within this theoretical and empirical framework, the main hypothesis of this paper is to test whether the real economic activity and the shadow interest rate have significant effects on the exchange rate and the foreign trade balance between the US, Brazil, Canada and Mexico and thus lead to changes in economic policy implementation. For this purpose, the nominal exchange rates, the industrial productions and the OECDbased recession indicator for the US are extracted from the statistical database of the Federal Reserve Bank of St. Louis. The UN Comtrade Database is also used as a source to generate the trade balance variables, while the shadow interest rate of the US is taken from the Reserve Bank of New Zealand. ${ }^{4}$ All series are seasonally adjusted with plausible techniques, and RATS 9.2 routines are employed for the empirical exercise.

The remainder of the paper is structured as follows: Section II reviews the relevant theoretical and empirical studies. Section III identifies the methodological issues and the empirical model to investigate the relationship between the real economic activity, shadow interest rate, exchange rate and foreign trade balance. Empirical data and analysis are presented in Section IV. Section V discusses results and policy implications and Section VI concludes the paper.

\footnotetext{
$\overline{4}$ For the details please see https://www.rbnz.govt.nz/research-and-publications/research-programme/ additional-research/measures-of-the-stance-of-united-states-monetary-policy/comparison-ofinternational-monetary-policy-measures.
} 


\section{Literature review}

After the 2008-2009 global financial crisis, the system of payments in the US economy underwent major disruptions, and the Fed's primary policy was in the form of monetary expansion. This monetary expansion policy was followed by other central banks, and the unconventional monetary policies implemented by the $\mathrm{ECB}, \mathrm{BoJ}$ and BoE influenced the domestic, macroeconomic and financial variables in developed countries. The international spillover effects of the unconventional monetary policies of the major developed central banks have become the subject of many studies (Rogers et al., 2014; Chen et al., 2014). Recently, Chen et al. (2016) investigated the effects of QE on emerging market economies (EMEs) and advanced economies (AEs) using a global VEC model, and found that the impact of QE for a decrease in the US corporate spread was more dominant than that for reducing the US term spread. Based on these results, it was stressed that the estimated effects on EMEs were larger than those for the US, indicating that US monetary spillover led to a boost in economic activity. The effects of these unconventional monetary policies were rapidly recognized in the financial markets, while the expansionary monetary policy of the Fed had significant impacts on the exchange rate. It has also been acknowledged that exchange rate regimes are determinative for the effectiveness of the monetary policy and the degree of the international spillover effect. In the scientific literature, there are studies suggesting that the effects of external shocks and changes in the monetary policy stance can be mitigated by a flexible exchange rate regime (Edwards, 2015; Obstfeld, 2015). In this context, Rohit and Dash (2018) employed a time-varying model to study the effects of exchange rate regimes to understand monetary policy spillovers using a set of AEs and EMEs. They found that in terms of the spillover effects, a flexible exchange rate regime in AEs is more insulating than the implementation of a managed float regime in EMEs. Moreover, Rohit and Dash (2018) found that signaling channels, risk taking, and portfolio rebalancing were more efficient in expressing the increase in spillovers in EMEs than in AEs.

The international spillover effect can be assessed based on both conventional and unconventional monetary policy. In this framework, the shadow interest rate developed by Krippner (2014) has come to the forefront, and this has been widely used in the scientific literature. Potjagailo (2017) used the shadow interest rate as a reflector of monetary policy and estimated a factor-augmented VAR model to demonstrate the spillover effects from the center to the periphery in Europe. It was found that spillovers on production were greater in peripheral countries with higher trade openness, whereas financial variables responded to a higher degree in financially integrated countries. In line with Rohit and Dash (2018), Potjagailo (2017) highlighted the importance of the exchange rate regime, and showed that there were stronger spillover effects in countries with fixed exchange rate regimes in terms of production and interest rates. Using a similar approach, Hajek and Horvath 
(2018) explored the monetary policy spillover effects of both the Euro area and the US on prices and economic activity in peripheral Euro area countries, using a global VAR model. Their results suggested that the magnitude of the monetary spillover effects was country-specific. They also indicated that the impacts of conventional monetary policy measures were stronger than those of unconventional ones. Barbosa et al. (2018) evaluated the effects of monetary policy spillovers from the Fed and the BoE on two peripheral European countries: Ireland and Portugal. Their primary concern was the bank lending channel of the transmission mechanism, and they detected heterogeneous transmission mechanisms that significantly influenced credit growth in Ireland and Portugal.

While the aforementioned studies generally evaluate the international spillover effect of monetary policy based on financial variables, the shadow interest rate is reflected in the current account balance, through the expenditure and investment decisions of domestic economic agents. Aizenman et al. (2016) analyzed the international transmission mechanism of monetary policy from the center economies to peripheral countries. More specifically, they identified the real and financial linkages among these countries, in terms of the reactions of the peripheral countries to the policy interest rate, stock prices, and the real effective exchange rates. It was found that maintaining exchange rate stability and financial openness strengthened the links between these two groups of countries, through policy interest rates and real exchange rate movements. On the other hand, it was shown to be important to take into consideration microeconomic relationships and all related economic units when evaluating the effects of the changes in interest rates on the current account balance. Using this framework, Hjortsoe et al. (2018) constructed an open economy DSGE model that was intended to examine the responses of the current account to a monetary policy shock. They also incorporated the role of financial regulation in their study, and enriched their model with the inclusion of a varying coefficient Bayesian panel VAR model. Hjortsoe et al. (2018) found that the current account generated more deficits in more liberalized financial markets following a monetary policy expansion. The effects of monetary policy decisions on the current account balance can be realized through various channels. At this point, the exchange rate and long-term interest rates will be affected as a result of the changes in monetary policy (Barakchian, 2015; Apostolou and Beirne, 2018), which in turn will have consequences on the current balance.

In our study, we discuss conventional and unconventional monetary policy in the US, changes in the real economic activity of the US and the macroeconomic and financial relations between Brazil, Canada and Mexico in terms of the exchange rate and the foreign trade balance. Although the exchange rate regime is considered to be important in this framework, in line with Potjagailo (2017) and Rohit and Dash (2018), the US, Brazil, Canada and Mexico implement an independently floating exchange rate regime, using the IMF classification. Thus, the assumption 
that the interaction between the variables used in our study may change depending on the exchange rate regime is weak. Additionally, monetary policy in the US is not subject to a specific classification according to the IMF, and is reflected in various indicators. ${ }^{5}$ Hence, our study focuses on the probability of a recession in the US economy and the presence of asymmetric effects.

\section{Model specification}

In this study, we estimate the Qual VAR model with monthly data from 2010:01 to 2018:02 which uses the latent variable $\left(y_{t}{ }^{*}\right)$ deriving from the OECD-based recession indicator. The other variables of the model consist of the shadow interest rate of the US $\left(s s r_{t}^{u s}\right)$, the nominal exchange rate $\left(f x_{t}^{\text {country }}\right)$, and the foreign trade balance $\left(f t_{t}^{\text {country }}\right)$. More specifically, the foreign trade balance is computed by subtracting the logarithmic imports of the US from the logarithmic exports of the US. The final specification of the Qual VAR model is confirmed according to the Lumsdaine-Papell unit root test results.

The specification of the Qual VAR model depends on the basis of a binary dependent variable, which is stimulated by a continuous latent variable $y_{t}^{*}$ : More specifically, $y_{t}$ can be defined as $y_{t}=\left\{\begin{array}{lll}0 & \text { if } y_{t}{ }^{*} \leq 0 \\ 1 & \text { if } & y_{t}{ }^{*} \geq 0\end{array}\right.$.

Thus, Equation 1 specifies the Qual VAR model.

$$
y_{t}^{*}=\mu_{y^{*}}+\Sigma_{l=1}^{\rho} \varphi_{l} y_{t-l}^{*}+\Sigma_{l=1}^{\rho} \beta_{l} X_{t-l}+\varepsilon_{t}, \varepsilon_{t} \approx N(0,1) .
$$

where $X_{t-l}$ denotes a set of explanatory variables and $\varphi$ and $\beta$ represent vectors of the coefficients; $\varepsilon_{t}$ corresponds to a random error term with standard normal distribution and $t=1, \ldots, T$ refers to the time index. We also use non-linear VAR modelling in line with Kilian and Vigfusson (2011) to expose the asymmetric relationship between the effects of positive and negative changes in the industrial production, the shadow interest rate, the nominal exchange rate and the foreign trade balance. Unlike the Qual VAR model, the non-linear VAR model follows the censored variable approach; and thus, the industrial production of the US (ind $d_{t}^{u s}$ ) is used instead of the OECD-based recession indicator. The remaining variables used in the non-linear VAR model are the same as in the Qual VAR model and their final specification is suggested by the unit root test results. Our non-linear VAR model depends on the censored VAR approach for the period from 2010:01 to 2018:02, whereupon IRFs and slope-based tests are estimated.

\footnotetext{
$\overline{5}$ For the details please see https://www.imf.org/external/np/mfd/er/2004/eng/0604.htm.
} 
In this respect, we follow the Kilian and Vigfusson (2011) approach which bases on the linear and symmetric and asymmetric data generating processes. ${ }^{6}$ The equations below form a censored variable VAR model framework; in other words, the asymmetric VAR model is employed to estimate the IRFs. The asymmetric VAR model can be written as follows;

$$
\begin{aligned}
& x_{t}=b_{10}+\sum_{i=1}^{p} b_{11, i} x_{t-i}+\sum_{i=1}^{p} b_{12, i} y_{t-i}+\varepsilon_{1, t} \\
& y_{t}=b_{20}+\sum_{i=1}^{r} b_{21, i} x_{t-i}+\sum_{i=1}^{r} b_{22, i} y_{t-i}+\sum_{i=1}^{r} g_{21, i} x_{t-i}^{+}+\varepsilon_{1, t}
\end{aligned}
$$

The equation (2) defines a linear VAR model exposing the effects of $x_{t}$ on $y_{t}$, whereas the equation (3) captures both the impacts of $x_{t}$ and $x_{t}^{+}$on $y_{t}$. Accordingly, the dynamic responses of $y_{t}$ to positive and negative changes in $x_{t}$ can be computed. We can express a set of equations considering both censored variables and nonlinear VAR model as below;

$$
\begin{aligned}
& s_{t}=b_{10}+\Sigma_{k=1}^{p} b_{11, k} s_{t-k}+\Sigma_{k=1}^{p} b_{12, k} \lambda_{t-k}+\varepsilon_{1, t} \\
& \lambda_{t}=b_{20}+\Sigma_{k=1}^{p} b_{21, k} s_{t-k}+\Sigma_{k=1}^{p} b_{22, k} \lambda_{t-k}+\Sigma_{k=1}^{p} g_{21, k} s_{t-k}^{+}+\varepsilon_{2, t}
\end{aligned}
$$

where $p$ denotes the lag order of the VAR model and $s_{t}$ is the variable whose possible asymmetric impacts is explored. $\lambda_{t}$ vector contains variables that can be affected by $s_{t}$. Equation (4) shows the linear symmetric model with $s_{t}$, while equation (5) includes both $s_{t}$ and censored variable of $s_{t}{ }^{+}$. The $s_{t}{ }^{+}$refers to the positive changes and it can be written that; $s_{t}^{+}=\left\{\begin{array}{ll}s_{t} & s_{t}>0 \\ 0 & s_{t} \leq 0\end{array}\right.$.

Thus, $b_{10}$ and $b_{20}$ in (2) and (3) are the vectors of intercept and dummy variables, respectively. $b_{12}$ and $b_{22}$ vectors incorporate the coefficients of the changes in $s_{t}$ and $g_{21}$ contains the vector of the coefficient of the censored variable. Finally, $\varepsilon_{1, t}$ and $\varepsilon_{2, t}$ correspond to the residual vectors of (4) and (5). In this study, a similar approach to Ulke and Berument (2016) is followed; however, the number of variables contained in $\lambda_{t}$ is 4 for each country.

Moreover, 3 VAR models for Brazil, Canada and Mexico are used and each quadrivariant VAR model can be specified as $\left(\text { ind }_{t}^{u s,+},{ }^{u s} r_{t}^{u s,+}, f x_{t}^{\text {country, },}, f_{t}^{\text {country }}\right)^{\prime}$ and $\left(i n d_{t}^{u s,-}, s s r_{t}^{u s,-}, f x_{t}^{\text {country,-}}, f t_{t}^{\text {country }}\right)^{\prime}$, respectively. Therefore, $i n d_{t}^{u s,+}, s s r_{t}^{u s,+}$ and $f x_{t}^{\text {country, }}+$ are derived by negative values to zero. More specifically, it is accepted that only increases influence the other variable of the model via censored variables

\footnotetext{
6 The data generation process of $x_{t}$ can both be accepted as symmetric and asymmetric in terms of the regression model; $x_{t}=\alpha_{1}+\varepsilon_{1, t}$. In this respect, the substitution of negative values of $x_{t}$ with zero generates a censored variable $x_{t}^{+}$. The censored variable can be written as: $x_{t}^{+}=\left\{\begin{array}{cc}x_{t}^{+} & x_{t}>0 \\ 0 & x_{t} \leq 0\end{array}\right.$
} 
approach and the final specification of the model variables are determined by the Lumsdaine-Papell unit root test results.

\section{Empirical data and analysis}

\subsection{Empirical data}

In order to specify the unit root properties of the model variables, we implement the Lumsdaine-Papell unit root test allowing multiple structural breaks. Table 1 indicates the unit root properties of the series and the break dates, while the ZivotAndrews and Lee-Strazicich unit root tests with multiple break tests are parallel to the Lumsdaine-Papell unit root test results.

Table 1: Lumsdaine-Papell unit root test results

\begin{tabular}{|l|c|c|c|}
\hline \multicolumn{1}{|c|}{ Variables } & Test statistic & $\begin{array}{c}\text { Number of lagged } \\
\text { differences by AIC }\end{array}$ & Suggested break date \\
\hline ind ${ }_{t}^{\text {us }}$ & -5.4719 & 5 & $2014: 12,2016: 05$ \\
\hline$\Delta i n d_{t}^{u s}$ & -9.2735 & 4 & $2014: 04,2015: 06$ \\
\hline$s s r_{t}^{u s}$ & -4.6962 & 1 & $2011: 05,2013: 12$ \\
\hline$\Delta s s r_{t}^{u s}$ & -8.2480 & 0 & $2011: 09,2013: 05$ \\
\hline$f x_{t}^{\text {brazil }}$ & -6.6059 & 2 & $2012: 07,2015: 12$ \\
\hline$f t_{t}^{\text {brazil }}$ & -9.2746 & 3 & $2012: 02,2015: 09$ \\
\hline$f_{t}^{\text {canada }}$ & -7.2133 & 3 & $2014: 08,2015: 12$ \\
\hline$f t_{t}^{\text {canada }}$ & -9.0004 & 10 & $2012: 09,2016: 07$ \\
\hline$f x_{t}^{\text {mexico }}$ & -8.1028 & 0 & $2012: 06,2016: 06$ \\
\hline$f t_{t}^{\text {mexico }}$ & -7.7929 & 10 & \\
\hline
\end{tabular}

According to $1 \%, 5 \%, 10 \%$ significance level, the critical values of the Lumsdaine-Papell unit root test are $-6.74,-6.16,-5.89$, respectively.

Source: Authors' calculations

According to Table 1, no cointegration relationship can be searched for all cases since some of the variables are I(0) and $i n d_{t}^{u s}$ and $s s r_{t}^{u s}$ are integrated of order 1 at levels. The Lumsdaine-Papell unit root test results suggest that each variable may have different structural breakdown data from the other. ${ }^{7}$ Bai-Perron tests have also confirmed that there can be multiple and different structural breaks for the model variables. Thus, we do not split the full-sample into particular sub-samples, and the Qual VAR and non-linear VAR models for each country are estimated on the full sample. According to the Lumsdaine-Papell unit root test results, the variables

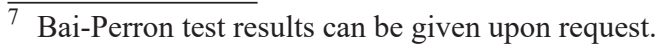


included in the non-linear VAR model are donated by $\Delta i n d_{t}^{u s}, \Delta s s r_{t}^{u s}, f x_{t}^{\text {country }}$ and $f t_{t}^{\text {country }}$. On the other hand, the Qual VAR model includes $y_{t}{ }^{*}, \Delta s s r_{t}^{u s}, f x_{t}^{\text {country }}$ and $f t_{t}^{\text {country. }}$.

In this study, we use Qual VAR and nonlinear VAR models for the US in order to examine its foreign exchange rates and foreign trade balances with Brazil, Canada and Mexico by forecasting and exploring the interactions between them. In VAR modeling, various information criteria are employed to specify the lag lengths of the Qual VAR and the nonlinear VAR models. ${ }^{8}$

\subsection{Qual VAR models' results}

Since the Fed's conventional and unconventional monetary policy decisions are based on changes in the real economic activity of the US, we analyze the impacts of real US business cycles and the shadow interest rate on the nominal exchange rate and the foreign trade balance in relation to the Brazilian, Canadian and Mexican economies. Thus, the effects of internal economic developments on external economic balances are evaluated. Using this framework, three different Qual VAR models are estimated. More specifically, the models can be represented in vector form as $\left(y_{t}{ }^{*}, \Delta s s r_{t}^{u s}, f x_{t}^{\text {brazil }}, f t_{t}^{\text {brazil }}\right)^{\prime},\left(y_{t}{ }^{*}, \Delta s s r_{t}^{u s}, f x_{t}^{\text {canada }}, f t_{t}^{\text {canada }}\right)^{\prime},\left(y_{t}{ }^{*}\right.$, $\left.\Delta s s r_{t}^{u s}, f x_{t}^{\text {mexico }}, f t_{t}^{\text {mexico }}\right)^{\prime}$, respectively. The values of the recession probabilities are reflected in an OECD-based recession indicator, which is the latent variable in the related models. In this context, the latent variable reflects the information from the macroeconomic variables in each Qual VAR model, and can be regarded as a business cycle indicator. Within the context of the OECD-based recession indicator the value of 1 corresponds to a recessionary period, while a value of 0 is an expansionary period. In terms of the OECD-based recession indicator, the latent variable $\left(y_{t}{ }^{*}\right)$ is derived and positive/negative values of $y_{t}{ }^{*}$ indicate the recessions and expansions. Thus, we forecast the probabilities of recession based on the latent variable for the US. As presented in Figure 1, none of the predicted probabilities are above the 0.5 level, suggesting that a recession is unlikely to occur in the US arising from the changes in $f x_{t}^{\text {brazil }}, f t_{t}^{\text {brazil }}, f x_{t}^{\text {canada }}, f t_{t}^{\text {canada }}, f x_{t}^{\text {mexico }}, f t_{t}^{\text {mexico }}$. However, given the model that includes variables relating to Mexico, it is possible to say that the probability of recession is lower than that in models with variables relating to Brazil and Canada.

\footnotetext{
8 The majority of the information criterion imposes the lag length of 1 for the Qual VAR models incorporating Brazilian and Mexican variables, whereas the lag length of 2 is suggested for the Qual VAR model with the Canadian data. The same lag lengths are also indicated for the non-linear models of each case.
} 
Figure 1: Predicted recession probabilities

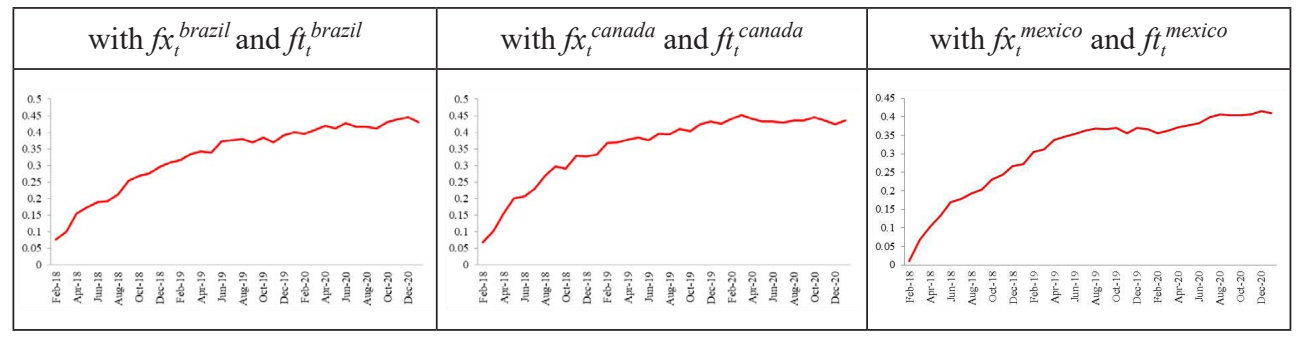

Source: Authors' calculations

In our study, unlike those of Dueker (2005) and Tillmann (2016), an impulseresponse analysis is performed on the Qual VAR model, and the effect of shocks in the latent variable on the other variables over the subsequent 24 months is shown in Figure 2. More precisely, the IRFs of the Qual VAR model depend on the normalized one unit shock in line with Dueker (2005).

Figure 2: Responses of the model variables to shocks in the latent variable

\begin{tabular}{|c|c|c|}
\hline $\begin{array}{c}\text { Responses of } \Delta s s r_{t}^{u s} \text { to shocks } \\
\text { of } y_{t}^{*}\end{array}$ & $\begin{array}{c}\text { Responses of } f x_{t}^{\text {brazil }} \text { to shocks } \\
\text { of } y_{t}^{*}\end{array}$ & $\begin{array}{c}\text { Responses of } f t_{t}^{b r a z i l} \text { to shocks } \\
\text { of } y_{t}{ }^{*}\end{array}$ \\
\hline 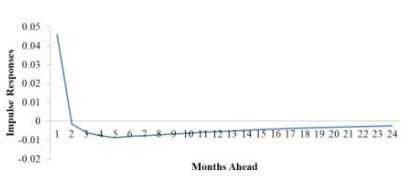 & $\underbrace{}_{\text {Sombith Aheal }}$ & 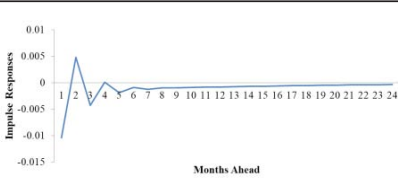 \\
\hline $\begin{array}{c}\text { Responses of } \Delta s s r_{t}^{u s} \text { to shocks } \\
\text { of } y_{t}{ }^{*}\end{array}$ & $\begin{array}{l}\text { Responses of } f x_{t}^{\text {canada }} \text { to shocks } \\
\text { of } y_{t}^{*}\end{array}$ & $\begin{array}{c}\text { Responses of } f t_{t}^{\text {canada }} \text { to shocks } \\
\text { of } y_{t}^{*}\end{array}$ \\
\hline 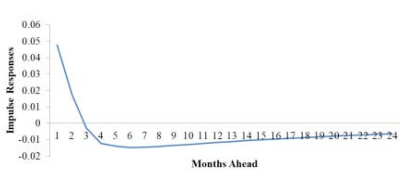 & 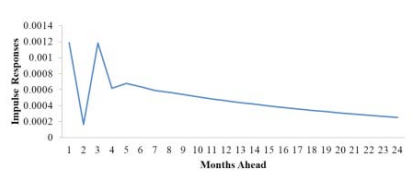 & 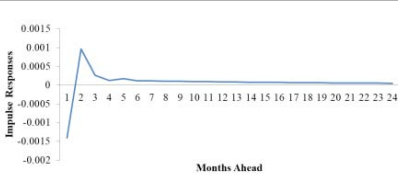 \\
\hline $\begin{array}{c}\text { Responses of } \Delta s s r_{t}^{u s} \text { to shocks } \\
\text { of } y_{t}^{*}\end{array}$ & $\begin{array}{c}\text { Responses of } f x_{t}^{\text {mexico }} \text { to shocks } \\
\text { of } y_{t}{ }^{*}\end{array}$ & $\begin{array}{c}\text { Responses of } f t_{t}^{\text {mexico }} \text { to shocks } \\
\text { of } y_{t}^{*}\end{array}$ \\
\hline 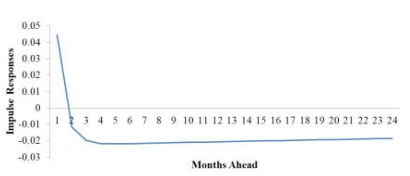 & 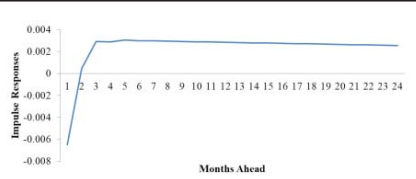 & 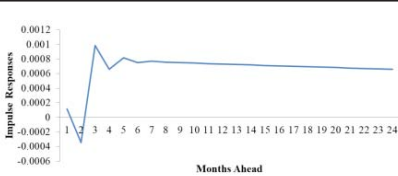 \\
\hline
\end{tabular}

Source: Authors' calculations 
Based on the results of the impulse-response analysis for all three models, we find that shocks in the recession indicator may cause expansionary conventional and unconventional monetary policy. In other words, it is likely that the shadow interest rate will drop, and may even take negative values, with an increase in the probability of recession.

In addition to the course of real economic activity, it can be argued that the macroeconomic and financial variables have changed significantly, and thus the probability of recession has increased/decreased as a result of the implementation of monetary policy. In our study, the effects of shocks in the shadow interest rate are also examined; within the framework of the impulse-response analysis of all three Qual VAR models reflected in Figure 3, we find that contractionary monetary policy increases the probability of an economic recession. Although an increase in the probability of economic recession is considered to be a factor triggering a financial crisis, the increase in net capital inflows to the US economy as a result of rising interest rates and hence the appreciation of the US dollar against the Brazilian real, the Canadian dollar and the Mexican peso are other crucial results of the impulseresponse analysis. However, the effects of real economic activity and the exchange rate on the foreign trade balance can sometimes produce the reverse results.

Figure 3: Responses of the model variables to shocks in the shadow interest rate

\begin{tabular}{|c|c|c|}
\hline $\begin{array}{c}\text { Responses of } y_{t}^{*} \text { to shocks of } \\
\Delta s s r_{t}^{u s}\end{array}$ & $\begin{array}{c}\text { Responses of } f x_{t}^{\text {brazil }} \text { to shocks } \\
\text { of } \Delta s s r_{t}^{u s}\end{array}$ & $\begin{array}{c}\text { Responses of } f t_{t}^{\text {brazil }} \text { to shocks } \\
\text { of } \Delta s s r_{t}^{u s}\end{array}$ \\
\hline 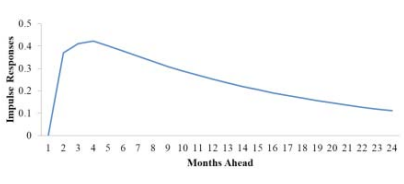 & 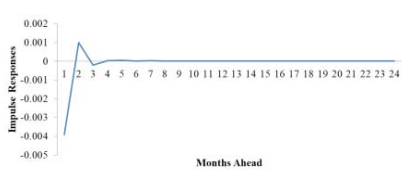 & 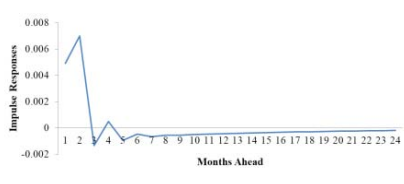 \\
\hline $\begin{array}{c}\text { Responses of } y_{t}^{*} \text { to shocks of } \\
\Delta s s r_{t}^{u s}\end{array}$ & $\begin{array}{c}\text { Responses of } f x_{t}^{\text {canada }} \text { to shocks } \\
\text { of } \Delta s s r_{t}^{u s}\end{array}$ & $\begin{array}{c}\text { Responses of } f t_{t}^{\text {canada }} \text { to shocks } \\
\text { of } \Delta s s r_{t}^{u s}\end{array}$ \\
\hline 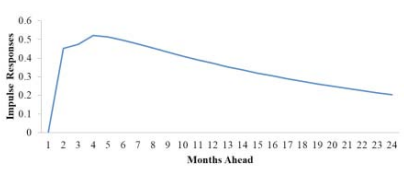 & 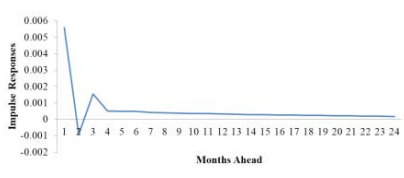 & 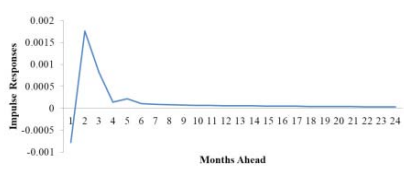 \\
\hline $\begin{array}{c}\text { Responses of } y_{t}^{*} \text { to shocks of } \\
\Delta s s r_{t}^{u s}\end{array}$ & $\begin{array}{c}\text { Responses of } f x_{t}^{\text {mexico }} \text { to shocks } \\
\text { of } \Delta s s r_{t}^{u s}\end{array}$ & $\begin{array}{c}\text { Responses of } f t_{t}^{\text {mexico }} \text { to shocks } \\
\text { of } \Delta s s r_{t}^{u s}\end{array}$ \\
\hline 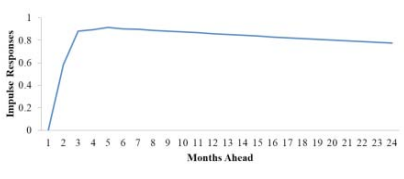 & 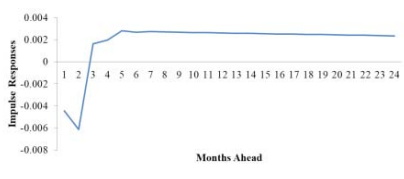 & 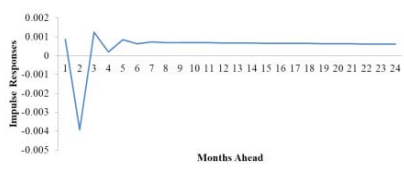 \\
\hline
\end{tabular}

Source: Authors' calculations 


\subsection{Nonlinear VAR models' results}

In this study, we also estimate a VAR model with censored variables, in accordance with Kilian and Vigfusson's (2011) approach. The presence of asymmetric effects is also examined with Mork and Wald's slope-based tests, and the results are presented in Table 2. These two tests produce opposite results in terms of the effects of the shadow interest rate on the foreign trade balance of the US with Brazil, Canada and Mexico. Based on a 1\% significance level for the Wald test, the impact of $\Delta s s r_{t}^{u s}$ on $f t_{t}^{\text {country }}$ can be regarded as asymmetric, while the Mork test suggests that the effect could be symmetric. Slope-based tests can account for the possible asymmetric effects of one variable on another, but cannot determine the direction and magnitude of the relationship.

Table 2: Slope-based test results

\begin{tabular}{|c|c|c|c|c|c|c|c|c|c|c|}
\hline \multirow{3}{*}{ Shock: } & \multirow{3}{*}{$\begin{array}{c}\Delta s s r_{t}^{u s} \\
(1)\end{array}$} & \multirow{3}{*}{$\begin{array}{c}\Delta_{\text {ind }}^{u s} \\
\text { (2) }\end{array}$} & \multicolumn{4}{|c|}{ Mork test } & \multicolumn{4}{|c|}{ Wald test } \\
\hline & & & \multicolumn{2}{|c|}{ Chi-squared } & \multicolumn{2}{|c|}{$p$-value } & \multicolumn{2}{|c|}{ Chi-squared } & \multicolumn{2}{|c|}{$p$-value } \\
\hline & & & 1 & 2 & 1 & 2 & $\begin{array}{ll}1 \\
\end{array}$ & 2 & 1 & 2 \\
\hline Response: & $\mathrm{fx}_{\mathrm{t}}^{\text {brazil }}$ & $\mathrm{fx}_{\mathrm{t}}^{\text {brazil }}$ & 7.95 & 1.18 & 0.005 & 0.278 & 3744.18 & 6847.98 & 0.000 & 0.000 \\
\hline Response: & $\mathrm{fx}_{\mathrm{t}}^{\text {canada }}$ & $\mathrm{fx}_{\mathrm{t}}^{\text {canada }}$ & 4.04 & 1.22 & 0.132 & 0.543 & 14014.53 & 4303.73 & 0.000 & 0.000 \\
\hline Response: & $\mathrm{fx}_{\mathrm{t}}^{\text {mexico }}$ & $\mathrm{fx}_{\mathrm{t}}^{\text {mexico }}$ & 1.70 & 2.34 & 0.192 & 0.126 & 2840.45 & 3125.03 & 0.000 & 0.000 \\
\hline Response: & $\mathrm{ft}_{\mathrm{t}}^{\text {brazil }}$ & $\mathrm{ft}_{\mathrm{t}}^{\text {brazil }}$ & 0.10 & 0.15 & 0.751 & 0.704 & 185.37 & 18.49 & 0.000 & 0.000 \\
\hline Response: & $\mathrm{ft}_{\mathrm{t}}^{\mathrm{c} \text { canada }}$ & $\mathrm{ft}_{\mathrm{t}}^{\text {canada }}$ & 3.33 & 0.70 & 0.190 & 0.704 & 61052.32 & 12999.93 & 0.000 & 0.000 \\
\hline Response: & $\mathrm{ft}_{\mathrm{t}}^{\text {mexico }}$ & $\mathrm{ft}_{\mathrm{t}}^{\text {mexico }}$ & 0.28 & 0.71 & 0.598 & 0.399 & 2089.24 & 29031.95 & 0.000 & 0.000 \\
\hline
\end{tabular}

Source: Authors' calculations

The role of asymmetry in the relationship between the conventional and unconventional monetary policy and the foreign trade balance is also studied using IRFs, in a similar way to that of Kilian and Vigfusson (2011). Thus, the effects of a one standard deviation shock are detected in the impulse-response analysis. The results of the IRFs of the nonlinear VAR model align with those of the Qual VAR model as shown in Figure 4; in other words, it can be argued that high interest rates will cause the US dollar to appreciate against the Brazilian real and the Mexican peso, which may be due to capital inflows from these emerging markets to the US economy. 
Figure 4: Responses of the exchange rate and the foreign trade balance to positive and negative shocks in the shadow interest rate

\begin{tabular}{|c|c|c|c|}
\hline $\begin{array}{c}\text { Responses of } f x_{t}^{\text {brazil }} \\
\text { to positive shocks of } \\
\Delta s s r_{t}^{u s}\end{array}$ & $\begin{array}{c}\text { Responses of } f x_{t}^{\text {brazil }} \\
\text { to negative shocks of } \\
\Delta s s r_{t}^{u s}\end{array}$ & $\begin{array}{c}\text { Responses of } f t_{t}^{\text {brazil }} \\
\text { to positive shocks of } \\
\Delta s s r_{t}^{u s}\end{array}$ & $\begin{array}{c}\text { Responses of } f t_{t}^{\text {brazil }} \\
\text { to negative shocks of } \\
\Delta s s r_{t}^{u s}\end{array}$ \\
\hline 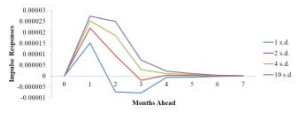 & $f$ & 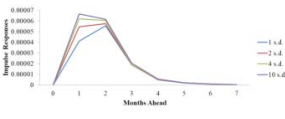 & 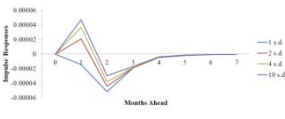 \\
\hline $\begin{array}{c}\text { Responses of } f x_{t}^{\text {canada }} \\
\text { to positive shocks of } \\
\Delta s s r_{t}^{u s}\end{array}$ & $\begin{array}{c}\text { Responses of } f x_{t}^{\text {canada }} \\
\text { to negative shocks of } \\
\Delta s s r_{t}^{u s}\end{array}$ & $\begin{array}{c}\text { Responses of } f t_{t}^{\text {canada }} \\
\text { to positive shocks of } \\
\Delta s s r_{t}^{u s}\end{array}$ & $\begin{array}{c}\text { Responses of } f t_{t}^{\text {canada }} \\
\text { to negative shocks of } \\
\Delta s s r_{t}^{u s}\end{array}$ \\
\hline$\sqrt{\mathbf{c}}$ & $\sqrt{1=0=1}=\sqrt{ }$ & & \\
\hline $\begin{array}{c}\text { Responses of } f x_{t}^{\text {mexico }} \\
\text { to positive shocks of } \\
\Delta s s r_{t}^{u s}\end{array}$ & $\begin{array}{l}\text { Responses of } f x_{t}^{\text {mexico }} \\
\text { to negative shocks of } \\
\Delta s s r_{t}^{u s}\end{array}$ & $\begin{array}{c}\text { Responses of } f t_{t}^{\text {mexico }} \\
\text { to positive shocks of } \\
\Delta s s r_{t}^{u s}\end{array}$ & $\begin{array}{c}\text { Responses of } f t_{t}^{\text {mexico }} \\
\text { to negative shocks of } \\
\Delta s s r_{t}^{u s}\end{array}$ \\
\hline 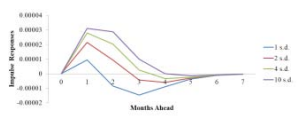 & 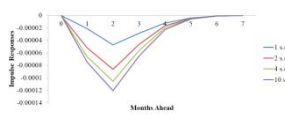 & & 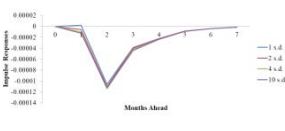 \\
\hline
\end{tabular}

Source: Authors' calculations

However, the impulse-response analysis conducted for Brazil and Canada reveals that the impacts of the expansionary monetary policies on the foreign trade balance are not symmetrical. In this context, we propose that the effects of expansionary monetary policy by the Fed on the foreign trade balance may not be dominant. On the other hand, in the same way as the IRFs of the Qual-VAR model, the nonlinear VAR model provides results showing that economic shrinkage positively affects the foreign trade balance. 
Figure 5: Responses of the exchange rate and the foreign trade balance to positive and negative shocks in the industrial production

\begin{tabular}{|c|c|c|c|}
\hline $\begin{array}{l}\text { Responses of } f x_{t}^{\text {brazil }} \\
\text { to positive shocks of } \\
\qquad i n d_{t}^{u s}\end{array}$ & $\begin{array}{c}\text { Responses of } f x_{t}^{\text {brazil }} \\
\text { to negative shocks of } \\
\Delta i n d_{t}^{u s}\end{array}$ & $\begin{array}{c}\text { Responses of } f t_{t}^{\text {brazil }} \\
\text { to positive shocks of } \\
\Delta i n d_{t}^{u s}\end{array}$ & $\begin{array}{c}\text { Responses of } f t_{t}^{\text {brazil }} \\
\text { to negative shocks of } \\
\Delta i n d_{t}^{u s}\end{array}$ \\
\hline$S_{+\ldots}$ & $\frac{1}{3 . .1}$ & . & 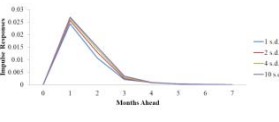 \\
\hline $\begin{array}{c}\text { Responses of } f x_{t}^{\text {canada }} \\
\text { to positive shocks of } \\
\Delta i n d_{t}^{u s}\end{array}$ & $\begin{array}{c}\text { Responses of } f x_{t}^{\text {canada }} \\
\text { to negative shocks of } \\
\Delta i n d_{t}^{u s}\end{array}$ & $\begin{array}{c}\text { Responses of } f t_{t}^{\text {canada }} \\
\text { to positive shocks of } \\
\Delta i n d_{t}^{u s}\end{array}$ & $\begin{array}{c}\text { Responses of } f t_{t}^{\text {canada }} \\
\text { to negative shocks of } \\
\Delta i n d_{t}^{u s}\end{array}$ \\
\hline 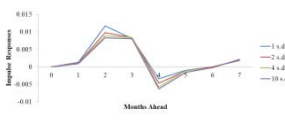 & 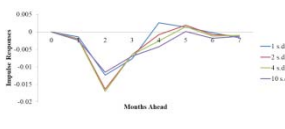 & & $\sqrt{n}$ \\
\hline $\begin{array}{l}\text { Responses of } f x_{t}^{\text {mexico }} \\
\text { to positive shocks of } \\
\qquad i n d_{t}^{u s}\end{array}$ & $\begin{array}{l}\text { Responses of } f x_{t}^{\text {mexico }} \\
\text { to negative shocks of } \\
\Delta i n d_{t}^{u s}\end{array}$ & $\begin{array}{c}\text { Responses of } f t_{t}^{\text {mexico }} \\
\text { to positive shocks of } \\
\qquad \Delta i n d_{t}^{u s}\end{array}$ & $\begin{array}{c}\text { Responses of } f t_{t}^{\text {mexico }} \\
\text { to negative shocks of } \\
\Delta i n d_{t}^{u s}\end{array}$ \\
\hline 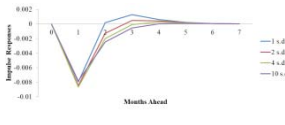 & 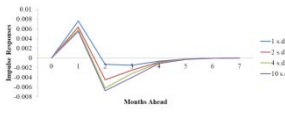 & 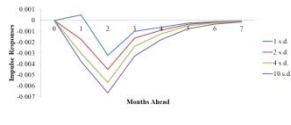 & Inses \\
\hline
\end{tabular}

Source: Authors' calculations

\section{Results and discussion}

In the context of the open economy macroeconomics, it has been acknowledged that the monetary policy has significant effects on the external equilibrium; more specifically, it can be suggested that the interest rate decisions of central banks will affect the current account balance of the relevant country through the changes in the real economic activity and in the real value of exchange rates. In line with the aforementioned assumptions, there are studies in the literature revealing that the monetary policy has significant impacts on the current account balance (Sariola, 2009; Cacciatore and Ghironi, 2013; Aizenman et al., 2016; Leibovici and Santacreu, 2016; Wong and Chong, 2016; Hjortsoe et al., 2018; Imura and Shukayev, 2019). Among these studies, Sariola (2009), Hjortsoe et al. (2018) and Imura and Shukayev (2019) discussed the effects of monetary policy shocks, aggregate demand shocks and exchange rate shocks on the current account balance by using standard VAR-type models. However, our study focuses on the asymmetrical effects of the shadow interest rate, the exchange rate and the aggregate demand shocks on the current account balance with the nonlinear VAR 
and Qual VAR models. Accordingly, this can be considered as an important feature of our study. As for the empirical results, Qual VAR models' IRFs have shown that an increase in the probability of recession in the US leads to reactions towards expansionary monetary policy. This argument also fulfils the Taylor rule and meets the Fed's post-GFC unemployment target. It is possible that the central bank, with the aim of drawing the country out of recession, will reduce interest rates to negative values. Real economic activity can also affect the pricing behaviors of economic units by influencing the inflation dynamics. The findings of our study are in line with this argument, and the IRFs of all three Qual VAR models show that the effects of shocks in the recession probability alleviate the inflationary pressures and cause the domestic currency to appreciate. A relationship between the probability of recession and the exchange rate as a financial variable can therefore be built via the inflation variable. It can also be argued that the probability of a recession may have impacts on the macroeconomic variables and the course of the economy. The impulse-response analysis of all three models shows that shocks in the probability of recession in the US can cause a foreign trade surplus in relation to Brazil, Canada and Mexico. This result can be considered a reflection of the decreasing demand for imports due to the recession. At this point, it can be said that the US has the most technologically powerful economy in the world, and households and firms make most of the decisions that influence the course of the economy. Since US business firms are assumed to have greater flexibility than those in Brazil, Canada and Mexico in terms of decisions to expand investments, to lay off surplus workers and to develop new products, it can also be suggested that Brazilian, Canadian and Mexican firms face higher barriers to entering the US market. Therefore, it should be kept in mind by the policymakers of those countries under investigation that a change in economic policy can have asymmetric effects on trade between the countries we are investigating.

In our study, an impulse-response analysis of all three Qual VAR models shows that a rise in the shadow interest rate may cause the US to develop foreign trade surpluses with Brazil, Canada and Mexico. It can therefore be argued that the results of the contractionary effect of high interest rates within the context of foreign trade may be dominant for the US economy. This implication can be line with the fact that improvement of credit conditions before the GFC caused a drop in the value of the dollar and deterioration in the US merchandise trade deficit, which peaked at $\$ 840$ billion in 2008 . However, it is important to examine the role of asymmetry. Additionally, it should be stressed that shrinkage of the domestic market conditions may push producers to seek alternative markets, and may increase US exports to Brazil, Canada and Mexico. Herein, it should be noted that Canada's major banks emerged from the GFC among the strongest in the world, owing to the financial sector's tradition of conservative lending practices and strong capitalization. In this respect, the reactions of the Canadian central bank to interest rate changes in the US and the country's trade relations with the US can also be recognized as considerable 
factors in formulating the optimal monetary and macroprudential policy conduction in Canada in the future.

According to the Mundell-Fleming model, it can be assumed that high interest rates adversely affect the foreign trade balance in the long run, in line with results reported by Sariola (2009), Barakchian (2015), Apostolou and Beirne (2018) and Imura and Shukayev (2019). Additionally, results based on IRFs show that an increase in the shadow interest rate has a more short-lived impact on US foreign trade with Brazil and Mexico than with Canada. This also shows that the level of trade and economic integration between the US and Brazil and Mexico may be lower than that between the US and Canada. Depending on the contractionary monetary policy in the US, the reactions of the Brazilian and Mexican central banks in terms of the interest rate hike may be much quicker, and thus some of the positive effects of the US on the foreign trade balance with both countries may be reduced. Nevertheless, it can be suggested that the continuation of the economic reforms in Brazil and economic and financial integration of the country with the US economy will be able to increase the competitiveness of the country in the long term. It can also be inferred that the reform program put into effect to slow the growth of government spending and reduce barriers to foreign investment can be effective in the long run.

On the other hand, we found asymmetric effects of the expansionary monetary policies on the foreign trade balance for Brazil and Canada. The probability of the Brazilian and Canadian central banks responding with a low interest rate policy similar to that applied in the US may be the reason for this outcome. When the foreign trade balance with Mexico is taken into consideration, it can be seen that the reduction in interest rates will be reflected negatively and permanently in the foreign trade balance, as shown by an impulse-response analysis and in line with the results of Hjortsoe et al. (2018). Goods and services produced in Mexico may increase rapidly, due to the expansion in the US economy. This finding also signifies the importance of foreign direct investments by US firms in Mexico, and thus the articulation of transnationalized production chains, trade in services and labor mobility across the US and Mexico and increased business cycle synchronization among the two countries, in accordance with the findings of Cacciatore and Ghironi (2013) and Potjagailo (2017). Those implications can be supported by the fact that Mexico has become the US's second-largest export market and thirdlargest source of imports. The interplay of the Mexican economy with the US in terms of production chains can be regarded as a factor in line with President Enrique Peña Nieto, who focused on economic reforms, passing and implementing sweeping energy, financial, fiscal and telecommunications reform legislation. Thus, it can be said that the continuation of the policies is important for improving the current balance of Mexico. The impulse-response analysis provides results that can be regarded as symmetrical, except for Canada, showing that expansionary/ 
contractionary monetary policies may lead to depreciation/appreciation of the US dollar against other currencies through capital flows parallel to Imura and Shukayev (2019).

In this study, the possible effects of industrial production on model variables were also investigated and it was found that a decrease in industrial production positively influences the foreign trade balance as shown in Figure 5. In this context, it can be expected that an expansion in economic activity will adversely affect the foreign trade balance, whereas the effects of positive shocks on industrial production do not have a significant impact direction in the long run. Figure 5 also indicates that the impacts of positive and negative shocks in the exchange rate on industrial production can be asymmetrical; moreover, it can be argued that the relationship between the real economic activity and the exchange rate cannot be strong when the impulse-response functions of the Qual VAR and the nonlinear VAR models are evaluated together.

\section{Conclusions}

In this study, we firstly evaluate the relationships between the real economic activity and the shadow interest rate, the nominal exchange rate and the foreign trade balance in the US. This is done within the framework of the most important trading partners in close geographical proximity to the US, using the OECDbased recession indicator for the US economy. The US-Brazil, US-Canada and US-Mexico relations are examined with the help of the Qual VAR model. More specifically, the recession probabilities in the US are evaluated by taking $f x_{t}^{\text {brazil }}$, $f t_{t}^{\text {brazil }}, f x_{t}^{\text {canada }}, f t_{t}^{\text {canada }}, f x_{t}^{\text {mexico }}, f t_{t}^{\text {mexico }}$ into account. Accordingly, it is exposed that changes in foreign trade between the US and Brazil, Canada and Mexico cannot create any significant changes in the business cycles in the US economy. Moreover, it can be said that the foreign trade with all three countries is likely to have negligible impacts on the US economy through the foreign trade channel. Since the Qual VAR model also includes the nominal exchange rate, it can be argued that the foreign exchange market, which affects the cross-exchange rates, will not change the real business cycles in the US due to the computed recession probabilities. On the other hand, it is acknowledged that the US, Brazilian, Canadian and Mexican economies are intertwined, especially in the production sector. Therefore, the role of the exchange rate and the foreign trade can become considerable factors in the future periods due to the changes in the economic conditions.

In our study, the impacts of recession shocks in the US on the other variables of the model are also examined with the Qual VAR model. In line with theoretical expectations, it is shown that an increase in the probability of a recession would positively affect the foreign trade balance of the US with Brazil, Canada and 
Mexico. In this context, we find that a contraction in the US economy will reduce the magnitude of the import demand. Additionally, since a contraction in the US economy will also lead to a decrease in the price level, the nominal exchange rate will appreciate in the context of PPP theory. Thus, it can be claimed that a recession in the US may have opposite consequences for the foreign trade balance. In addition to the real business cycles in the US economy, the Fed will also have impacts on the exchange rate and the foreign trade balance. An impulse-response analysis of the Qual VAR model shows that contractionary monetary policy in the US may cause a foreign trade surplus with Brazil, Canada and Mexico. In addition to these findings, which are in accordance with theoretical expectations, the validity of the UIP condition is not supported for the US, due to the fact that a rise in the shadow interest rate leads to the depreciation of the US dollar due to capital outflows.

It is also shown that the impacts of changes in the real economic activity and monetary policy on macroeconomic and financial variables may be asymmetrical in the non-linear VAR model. More specifically, an increase in the shadow interest rate raises the capital inflows to the US economy, and leads to the appreciation of the US dollar against the Brazilian real and the Mexican peso. Similarly, it is found that both conventional and unconventional expansionary monetary policies by the Fed cause capital outflows from the US. At this point, it can be said that the capital flows between the US and Canada will be under the influence of various macroeconomic and financial dynamics rather than changes in monetary policy. Based on the IRFs in the model, we show that the foreign trade balance of the US with Brazil, Canada and Mexico will be positively affected by an increase in the shadow interest rate. However, it is revealed that the decrease in the shadow interest rate in the US would not affect the foreign trade balance with Brazil and Canada in an apparent direction. In this context, it can be assumed that the effect of the US conventional and unconventional monetary policy in the foreign trade balance with these two countries can be asymmetrical. It can also be suggested that the US foreign trade balance with Mexico is positively affected by the shadow interest rate, and thus the effect in this context may be symmetrical. Only the slope-based tests do not support a symmetrical effect. As a result, the findings of our study suggest that the shortterm or asymmetric effects of the foreign trade balance in US monetary policy may be related to both the interest rate decisions of the central banks of Brazil, Canada and Mexico, and the levels of direct capital investments and economic integration of the US in these countries.

Significant limitations of this study can be twofold; (i) our sample period is relatively limited, from the first month of 2010 and to the second month of 2018 due to data availability, (ii) the model results can be under the influence of the microeconomic dynamics; however, any microvariables are included in the models. Our study highlights the importance of the clarification of all possible channels influencing the interactions between the real economic activity, shadow 
interest rate, exchange rate and foreign trade balance. We conclude that the monetary authorities of the US, aiming to achieve macroeconomic and financial stability, should determine the optimal theoretical and empirical framework for the evaluation of the interplay between the real economic activity; shadow interest rate; USD/BRL, USD/CAD, USD/MXN; foreign trade with Brazil, Canada and Mexico within the DSGE framework which is also the scope of further studies. Nevertheless, we suggest that the optimal control theory can also be adapted to increase the effectiveness of the monetary policy in the US considering the minimal volatility generating impact of the exchange rate and foreign trade balance on the US economy.

\section{References}

Aizenman, J., Chinn, M.D., Ito, H. (2016) "Monetary policy spillovers and the trilemma in the new normal: Periphery country sensitivity to core country conditions", Journal of International Money and Finance, Vol. 68, pp. 298330, doi: 10.1016/j.jimonfin.2016.02.008.

Apostolou, A., Beirne, J. (2018) "Volatility spillovers of unconventional monetary policy to emerging market economies", Economic Modelling, doi: 10.1016/j. econmod.2018.10.006.

Barakchian, S.M. (2015) "Transmission of US monetary policy into the Canadian economy: A structural cointegration analysis", Economic Modelling, Vol. 46, pp. 11-26, doi: 10.1016/j.econmod.2014.10.036.

Barbosa, L., et al. (2018) "Cross-border spillovers of monetary policy: What changes during a financial crisis?", Journal of International Money and Finance, Vol.89, pp. 154-174, doi: 10.1016/j.jimonfin.2018.08.006.

Cacciatore, M., Ghironi, F. (2013) "Trade, Unemployment, and Monetary Policy", Society for Economic Dynamics Meeting Paper, Vol. 724, pp. 1-43.

Chen, Q., et al. (2014) "Financial Crisis, Unconventional Monetary Policy and International Spillovers", Hong Kong Institute for Monetary Research Working Papers, Vol. 23, pp. 1-118.

Chen, Q., et al. (2016) "Financial crisis, US unconventional monetary policy and international spillovers", Journal of International Money and Finance, Vol. 67, pp. 62-81, doi: 10.1016/j.jimonfin.2015.06.011.

Dueker M. (2005) "Dynamic Forecasts of Qualitative Variables: A Qual VAR Model of U.S. Recessions", Journal of Business \& Economic Statistics, Vol. 23, pp. 96-104, doi: 10.1198/073500104000000613.

Edwards, S. (2015) "Monetary Policy Independence under Flexible Exchange Rate: An Illusion?", NBER Working Paper Series, No. 20893, pp. 1-20, doi: 10.3386/ w20893. 
Gajewski, K., et al. (2019) "International spillovers of monetary policy: Lessons from Chile, Korea, and Poland", Journal of International Money and Finance, Vol. 90, pp. 175-186, doi: 10.1016/j.jimonfin.2018.08.009.

Hajek, J., Horvath, R. (2018) "International spillovers of (un)conventional monetary policy: The effect of the ECB and the US Fed on non-euro EU countries", Economic Systems, Vol. 42, pp. 91-105, doi: 10.1016/j.ecosys.2017. 10.001 .

Hjortsoe, I., Weale, M., Wieladek, T. (2018) "How does financial liberalisation affect the influence of monetary policy on the current account?", Journal of International Money and Finance, Vol.85, pp. 93-123, doi: 10.1016/j.jimonfin. 2018.03.015.

Imura, Y., Shukayev, M. (2019) "The extensive margin of trade and monetary policy", Journal of Economic Dynamics \& Control, Vol. 100, pp. 417-441, doi: 10.1016/j.jedc.2019.01.002.

Kilian, L., Vigfusson, R.J. (2011) "Are the responses of the U.S. economy asymmetric in energy price increases and decreases?", Quantitative Economics, Vol. 2, pp. 419-453, doi: 10.3982/QE99.

Krippner, L. (2014) "Measuring the stance of monetary policy in conventional and unconventional environments", Centre for Applied Macroeconomic Analysis, Vol. 6, pp. 1-37.

Leibovici, F., Santacreu, A.M. (2016) "International Trade Fluctuations and Monetary Policy", Society for Economic Dynamics Meeting Paper, Vol. 367, pp. 1-24.

Obstfeld, M. (2015) "Trilemmas and Tradeoffs: Living with Financial Globalization", BIS Working Papers, No. 480, pp. 1-63.

Potjagailo, G. (2017) "Spillover effects from Euro area monetary policy across Europe: A factor-augmented VAR approach", Journal of International Money and Finance, Vol. 72, pp. 127-147, doi: 10.1016/j.jimonfin.2017.01.003.

Rogers, J.H., Scotti, C., Wright, J.H. (2014) "Evaluating Asset-Market Effects of Unconventional Monetary Policy: A Cross-Country Comparison", Board of Governors of the Federal Reserve System International Finance Discussion Papers, No. 1101, pp. 1-65.

Rohit, A.K., Dash, P. (2018) "Dynamics of monetary policy spillover: The role of exchange rate regimes", Economic Modelling, doi: 10.1016/j.econmod.2018. 09.007.

Sariola, M. (2009) "Monetary policy and exchange rate shocks: effects on foreign trade in Finland", Ministry of Finance (Finland) Discussion Paper, No. 2, pp. $1-40$.

Tillmann, P. (2016) "Unconventional monetary policy and the spillovers to emerging markets", Journal of International Money and Finance, Vol. 66, pp. 136-156, doi: 10.1016/j.jimonfin.2015.12.010. 
Wong, K-M., Chong, T.T-L. (2016) “Does monetary policy matter for trade?", International Economics, Vol. 147, pp. 107-125, doi: 10.1016/j.inteco.2016.04.001.

Ulke, V., Berument, H. (2016) "Asymmetric effects of monetary policy shocks on economic performance: empirical evidence from Turkey", Applied Economics Letters, Vol. 23, No. 5, pp. 353-360, doi: 10.1080/13504851.2015.1073836.

Unger, R. (2017) "Asymmetric credit growth and current account imbalances in the euro area", Journal of International Money and Finance, Vol. 73, pp. 435-451, doi: 10.1016/j.jimonfin.2017.02.017.

\title{
Uloga asimetrije u interakciji unutarnjih i vanjskih čimbenika: empirijski dokazi na prımjeru SAD-a, Brazila, Kanade i Meksika
}

\author{
Kaya Tokmakcioglu ${ }^{1}$, Oguzhan Ozcelebi ${ }^{2}$, Ali Sezin Ozdemir ${ }^{3}$
}

\begin{abstract}
Sažetak
U ovom istraživanju ispitana je realna ekonomska aktivnost i monetarna politika $S A D-a$ u usporedbi $s$ vanjskotrgovinskom bilancom $i$ valutnim tečajevima, primjenjujući modele Qual VAR i nelinearni VAR model. Ustanovili smo da međunarodno poslovanje s Brazilom, Kanadom i Meksikom ne dovodi do moguće recesije u SAD-u. Vrijednost domaće valute Brazila, Kanade i Meksika u odnosu na američki dolar ne pridonosi mogućoj recesiji na deviznom tržištu. Također smo pokazali da će kontrakcija američke ekonomije i kontrakcijska monetarna politika dovesti do aprecijacije američkog dolara vodeći do priljeva kapitala. Iako negativna stopa federalnih fondova (shadow interest rate) može imati asimetrične učinke na vanjskotrgovinsku bilancu s Kanadom i USD / CAD-om, smatramo da će vanjskotrgovinska bilanca s Meksikom i USD / MXN biti pozitivno ili negativno uvjetovana povećanjem odnosno smanjenjem stope federalnih fondova.
\end{abstract}

Ključne riječi: negativna stopa federalnih fondova (shadow interest rate), devizni tečaj, vanjskotrgovinska bilanca, Qual VAR, nelinearni VAR

JEL klasifikacija: E44, F31, F41

1 Izvanredni profesor, Faculty of Management Engineering, Department of Management Engineering, Istanbul Technical University. Macka Campus, 34343 Besiktas, Istanbul, Turska. Znanstveni interes: monetarna ekonomija, međunarodna ekonomija, financije. Tel.: +90 212 2931300 (205-113).E-mail: tokmakcioglu@itu.edu.tr.

2 Izvanredni profesor, Faculty of Economics, Department of Economics, Istanbul University. Beyazit Campus, 34542 Beyazit, Istanbul, Turska. Znanstveni interes: monetarna ekonomija, međunarodna ekonomija, makroekonomija, primijenjena ekonomija, DSGE modeliranje. Tel.: +902124400000 (11789).Fax:+90212 5208682.E-mail: ogozc@istanbul.edu.tr.

3 Doktorand, Faculty of Management Engineering, Department of Management Engineering, Istanbul Technical University. Macka Campus, 34343 Besiktas, Istanbul, Turska. Znanstveni interes: monetarna ekonomija, međunarodna ekonomija, financije. Tel.: +90 2122931300 (205-113).E-mail: ozdemiralisezin@gmail.com. 
